\title{
CONSTITUTION OF THE AMERICAN ASTRONOMICAL SOCIETY
}

Adopted September 1899; Amended December 1906, August 1912, August 1914, August 1915, September I919, August 1929, September 1930, December 1947, June 1949, December 1949, December 1950, December I95I.

\section{ARTICLE I-NAME AND PURPOSE}

I. This Association shall be called the American Astronomical Society.

2. The purpose of this Society is the advancement of astronomy and closely related branches of science.

\section{ARTICLE II-MEMBERSHIP}

I. Those persons whose names were signed on or before September 15, I899, to the statement of desire to form such an association shall constitute the charter members of this Society. The charter members, together with such other persons as may be elected by the Council hereinafter provided, shall constitute the members of the Society.

2. Upon nomination by not less than five members, the Council may elect to honorary membership one astronomer of distinction at each annual meeting. American astronomers shall not be eligible to honorary membership. Honorary members shall be exempt from dues or assessments, and shall be entitled to all the privileges of the Society.

3. Any person who has rendered conspicuous service to astronomy otherwise than through scientific contributions may be elected by the Council to be a patron of the Society.

4. The Council shall prepare and publish in the form of by-laws uniform rules for the election of members.

\section{ARTICLE III-OFFICERS AND COUNCIL}

(Amended March 1956)

I. The officers of the Society shall consist of a president, president-elect, two vice-presidents, a secretary, and a treasurer, who in addition to the duties specifically assigned to them by this Constitution shall discharge the other duties usually incident to their respective offices.

2. The Council shall consist of the officers, the two available ex-presidents whose presidential terms have most recently expired, provided they have served their full terms, and of nine councillors elected from the membership of the Society. The management of all affairs of the Society not otherwise provided for shall be entrusted to the Council. The president and the secretary of the Society shall serve respectively as chairman and secretary of the Council. Each officer of the Society shall be responsible to the Council and shall administer his office in accordance with its instructions.

3. The word "Council" as herein used and the word "Directors" as used in the Articles of Incorporation shall be held to mean one and the same thing, and the Council shall exercise all of the functions of the Directors and the Directors shall exercise all of the functions of the Council.

4. The term of office shall be two years for the president with one additional year as presidentelect, two years for the vice-presidents, three years for the secretary, three years for the treasurer, and three years for each of the nine councillors. The president-elect, who shall assume the office of president immediately after a regular annual meeting, shall be chosen as president-elect at the preceding annual meeting. The president-elect shall be nominated only from among those members of the Society who have served at least one year on the Council. The president, vice-presidents, and nine councillors shall not be eligible for immediate re-election.

5. If the president of the Society should die or resign before the expiration of his term of office, the president-elect shall act as president for the remainder of the unexpired term and shall then continue to serve the term for which he was originally elected. If no president-elect exists, the senior vice-president shall act as president until the next annual meeting, when a president shall be elected by the Society. Vacancies which may exist at any time in the offices of secretary or treasurer may be filled temporarily by the Council. If a vice-president or a councillor should die or resign more than one year before the expiration of his term, the vacancy for the unexpired term shall be filled by the Society at the next annual meeting. 